\title{
Selected Economic and Environmental Indicators in EU28 Countries Connected with Climate Protection
}

\author{
Jarmila Zimmermannová and Vít Pászto
}

\begin{abstract}
The main goal of this chapter is to present the development of selected economic and environmental indicators in EU28 countries connected with climate protection in the period from 2005 to 2015. European Union Emission Trading Scheme (EU ETS) was introduced in 2005. Currently, the EU ETS is in operation for more than a decade; moreover, in 2018, the European Commission adopts rules for the next 4th trading period. Is there visible any improvement in $\mathrm{CO}_{2}$ emissions development? Can it be connected to the changes in the macroeconomic indicators? The methodological part presents the data sources and methodological background of the research. Possible geographical patterns in the development of selected indicators within the EU28 are indicated. Detailed analysis of economic and environmental data of EU28 countries is provided, with the use of (geo)visual analysis of the data. The results of the (geo) visual analysis show that $\mathrm{CO}_{2}$ emissions within
\end{abstract}

\section{J. Zimmermannová}

Department of Economics, Moravian Business College

Olomouc, Olomouc, Czech Republic

e-mail: jarmila.zimmermannova@mvso.cz

V. Pászto $(\bowtie)$

Department of Informatics and Applied Mathematics, Moravian Business College Olomouc, Olomouc, Czech Republic

Department of Geoinformatics, Palacký University Olomouc, Olomouc, Czech Republic

e-mail: vit.paszto@gmail.com selected EU countries were decreasing in the chosen period 2005-2015, with some exceptions (e.g. Iceland and Latvia). As the development of $\mathrm{CO}_{2}$ emissions in all selected EU countries is not similar, the other economic and environmental indicators were included (e.g. GDP, Investments) into the analysis to reveal a typical (geographical) pattern and explain the current situation.

\section{Keywords}

Carbon dioxide $\cdot$ Emissions $\cdot$ Spatial pattern . (Geo)visual analysis · Maps

\subsection{Relationships Between Economic and Environmental Indicators}

The development of economic and environmental indicators in particular countries can be influenced by different factors. The researchers and analytics can observe the development of specific indicators in the same direction, increase in both kinds of indicators (positive development) or decrease in both types of indicators (negative development). Regarding the reduction of the environmental burden of the economy, the best possibility is positive development of economic indicators and negative development of environmental indicators; referred to as "decoupling".

Decoupling environmental pressures from economic growth are one of the main objectives 
of the OECD Environmental Strategy for the First Decade of the twenty-first century, adopted by OECD Environment Ministers in 2001. Decoupling occurs when the growth rate of an environmental pressure is less than that of its economic driving force (e.g. GDP) over a given period. Decoupling can be either absolute or relative. Absolute decoupling is said to occur when the environmentally relevant variable is stable or decreasing while the economic driving force is growing. Decoupling is said to be relative when the growth rate of the environmentally relevant variable is positive but less than the growth rate of the economic variable (OECD 2002).

Except for some pressures, decoupling is usual in OECD countries, and further progress seems possible. The evidence presented in the OECD Report "Indicators to Measure Decoupling of Environmental Pressure from Economic Growth" shows that relative decoupling is widespread in OECD Member countries. Absolute decoupling is also quite common, but for some environmental pressures, little decoupling is occurring. The evidence also suggests that further decoupling is possible since absolute decoupling was recorded in at least one OECD country for all but two of the decoupling indicators examined at the national level.

The OECD report explores a set of 31 decoupling indicators is covering a broad spectrum of environmental issues. Sixteen indicators related to the decoupling of environmental pressures from total economic activity under the headings of climate change, air pollution, water quality, waste disposal, material use and natural resources. The remaining 15 indicators focus on production and use in four specific sectors: energy, transport, agriculture and manufacturing. Some indicators have also been decomposed to highlight the extent to which various factors (e.g. technological factors, structural changes) have contributed to reducing or adding to environmental pressures in recent years.

Regarding our analysis, we will deal with selected economic and environmental indicators in EU countries, with a focus on climate protection and $\mathrm{CO}_{2}$ emissions development.

\subsection{The EU Emissions Trading System Background}

The European Union established a scheme for emission allowances trading, the EU Emissions Trading System, also called as the EU ETS. Currently, the EU ETS is in operation for more than a decade; moreover, in 2018, the European Commission adopts rules for the next 4th trading period. The initial EU Emissions Trading System was based on Directive 2003/87/EC, which established a fundamentally decentralised system for the pilot phase of emissions trading (2005-2007) and the Kyoto Protocol commitment phase (2008-2012). The key instrument was the preparation of National Allocation Plans (NAPs) (Wettestad et al. 2012).

Currently, the EU ETS is the most significant emissions market in the world. Based on Directive 2009/29/EC, the EU ETS is in Phase III (2013-2020), the post-Kyoto commitment period.

The regulatory framework of the EU ETS was mostly unchanged for the first two trading periods of its operation, the beginning of the third trading period in 2013 brings changes in standard rules (based on Directive 2009/29/EC), which should strengthen the system - from the year 2013 the most important yield of the emission allowances is auctioned. Sectorial differentiation was introduced, with (initially) far more auctioning of allowances for energy producers than energyintensive industries. Also, free allocations were further harmonised, to be based on joint state-ofthe-art technology benchmarks (Wettestad et al. 2012, p. 73). Policymakers give firms an incentive to move towards production that is less fossilfuel intensive (Aatola et al. 2013).

In the last years, $\mathrm{CO}_{2}$ became a significant member of the European commodity trading market. However, there is a fundamental difference between trading in $\mathrm{CO}_{2}$ and more traditional commodities. Sellers are expected to produce fewer emissions than they are allowed to, so they may sell the unused allowances to someone who emits more than the allocated amount. Therefore, the emissions become either an asset 
or a liability for the obligation to deliver allowances to cover those emissions (Benz and Trück 2009).

Generally, the market price of the allowances is determined by supply and demand. However, there can also be other so-called "price drivers". Both in the first and the second trading period, the EU emission allowances were traded mostly on the BlueNext trading exchange (BlueNext 2012). In the third trading period, there has only been one significant exchange which can be used for emission rights trading - European Energy Exchange - EEX (EEX 2018).

EEX has offered to trade of emission allowances on the base of the EU ETS since 2005. EEX currently runs a secondary market for continuous trading on a Spot and Derivatives basis for EU ETS allowances (European Emissions Allowances - EUA, European Aviation Allowances - EUAA) and Kyoto credits (CER, ERU). In addition to the secondary market, EEX conducts large-scale primary auctions of emissions allowances on behalf of the EU Member States as well as for Germany and Poland, held 4 days per week. In the framework of these auctions, emission allowances are issued to the market participants for the first time (EEX 2018).

The EU ETS covers more than 11,000 power stations and manufacturing plants in the $28 \mathrm{EU}$ member states as well as Iceland, Liechtenstein and Norway. Aviation operators flying within and between most of these countries are also covered. In total, around $45 \%$ of total EU emissions are limited by the EU ETS (European Commission 2013). The EU ETS includes both European Emissions Allowances - EUAs (since 2005) and European Aviation Allowances - EUAAs (since 2012). The market price of the allowances is determined by supply and demand at the exchange.

Generally, the first period (2005-2007) of the EU ETS was a three-year pilot period for the preparation for the second, Kyoto based, period (2008-2012). Emission allowances were allocated for free (grandfathering), based on the National allocation plans and historical emissions. The first period aimed to establish a carbon market, determine the market price of carbon and build the necessary infrastructure for monitoring, reporting and verifying actual emissions. The data generated from the first period subsequently filled the information gap and helped to set national emission limits (caps) for the second phase. The EUA spot price fluctuated between $25 \mathrm{EUR} / \mathrm{t} \mathrm{CO}_{2}$ at the beginning of the period and the nearly zero level at the end of the period.

The second period (2008-2012) corresponds with the targets set under the Kyoto Protocol. The European Union committed itself to achieve an overall $8 \%$ reduction in $\mathrm{CO}_{2}$ emissions in the period 2008-2012 compared to 1990 levels. Based on the verified emissions reported in the first period, the volume of emission allowances allocated in the second period was reduced by $6.5 \%$ compared to the level of Y2005. The EUA spot price fluctuated in the range 6-25 EUR/t $\mathrm{CO}_{2}$.

The development of EUA price in the first and the second period of EU ETS (2005-2012) is presented in Fig. 15.1.

In the third, post-Kyoto period (2013-2020), the conditions for the functioning of the EU ETS have changed in connection with so-called Climate and Energy Package, based on the amendment of Directive 2003/87/EC by Directive 2009/ 29/EC. Moreover, the new directive on $\mathrm{CO}_{2}$ geological storage was adopted, and the European Commission presented the EU's energy and climate change targets for 2020 (known as the 20-20-20 targets). One of these objectives was also to reduce EU greenhouse gas emissions by 20\% compared to 1990 levels. Since the EU emission allowances were previously grandfathered, from the year 2013, the significant yield of the emission allowances is auctioned. Grandfathering was widely criticised, mostly because it introduced significant distortions to the EU ETS (Falbo et al. 2013). Auctioning is the most transparent method of allocating allowances and puts into practice the polluter pays principle (European Commission 2013). Sectorial differentiation was also introduced, with (initially) far more auctioning of allowances for energy producers than energy-intensive industries. The development of EUA price in the 


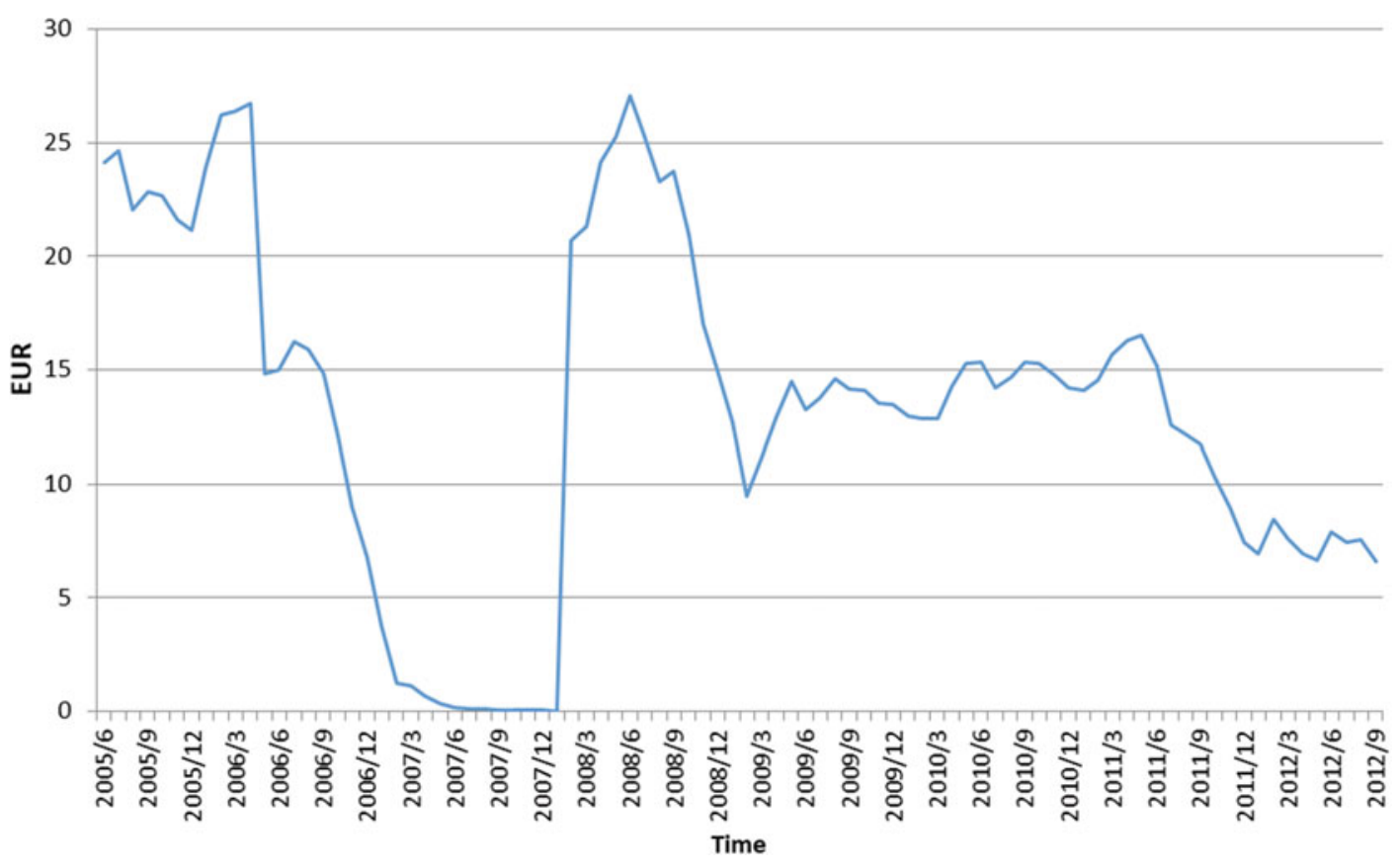

Fig. 15.1 EUA price development 2005-2012. (Source: BlueNext 2012; EEX 2018)

third period of EU ETS (2013-2018) is presented in the following Fig. 15.2.

Currently, the fourth phase of the EU ETS (2021-2028) is prepared, known as the "Post2020 Reform of the EU Emissions Trading System". At the beginning of Y2018, the fourth phase of the EU ETS has been approved by both the European Parliament and the EU Council. On 19 March 2018, the final text of Directive 2018/ 410/EU amending Directive 2003/87/EC to enhance cost-effective emission reductions and low-carbon investments was published in Official Journal of the European Union.

The key questions are - (1) Was the amount of $\mathrm{CO}_{2}$ emissions increasing or decreasing during the previous periods of EU ETS, and (2) Is it possible to observe geographical similarities within the EU countries connected with their economic and environmental indicators?

This chapter focuses on the evaluation of the development of $\mathrm{CO}_{2}$ emissions and selected economic indicators of EU28 countries in the period from 2005 to 2015 - the year 2005 is the first year of the EU ETS introduction and year 2015 represents the significant year with $\mathrm{CO}_{2}$ emissions available data. As a next task, the chapter will examine and evaluate possible geographical pattern in the development of selected indicators within the EU. Analysis of a geographic pattern and spatial distribution of countries emitting pollution is essential due to a common geopolitical context of such countries. The chapter will provide a detailed spatial analysis of economic and environmental data of EU28 countries, with the use of (geo)visual analysis of spatial data and spatial statistics (grouping analysis). Obtained results will be presented using analytical maps.

\subsection{Methods and Data}

For the analysis, the Eurostat database contains greenhouse gas emissions and corresponding macroeconomic data that were used to cover the years 2005 and 2015 (Eurostat, 2018). Namely, all sectors' indirect $\mathrm{CO}_{2}$ emissions in total, fuel combustion in energy industries, Gross domestic product at market prices, and Gross capital formation. Geographically, all indicators were 


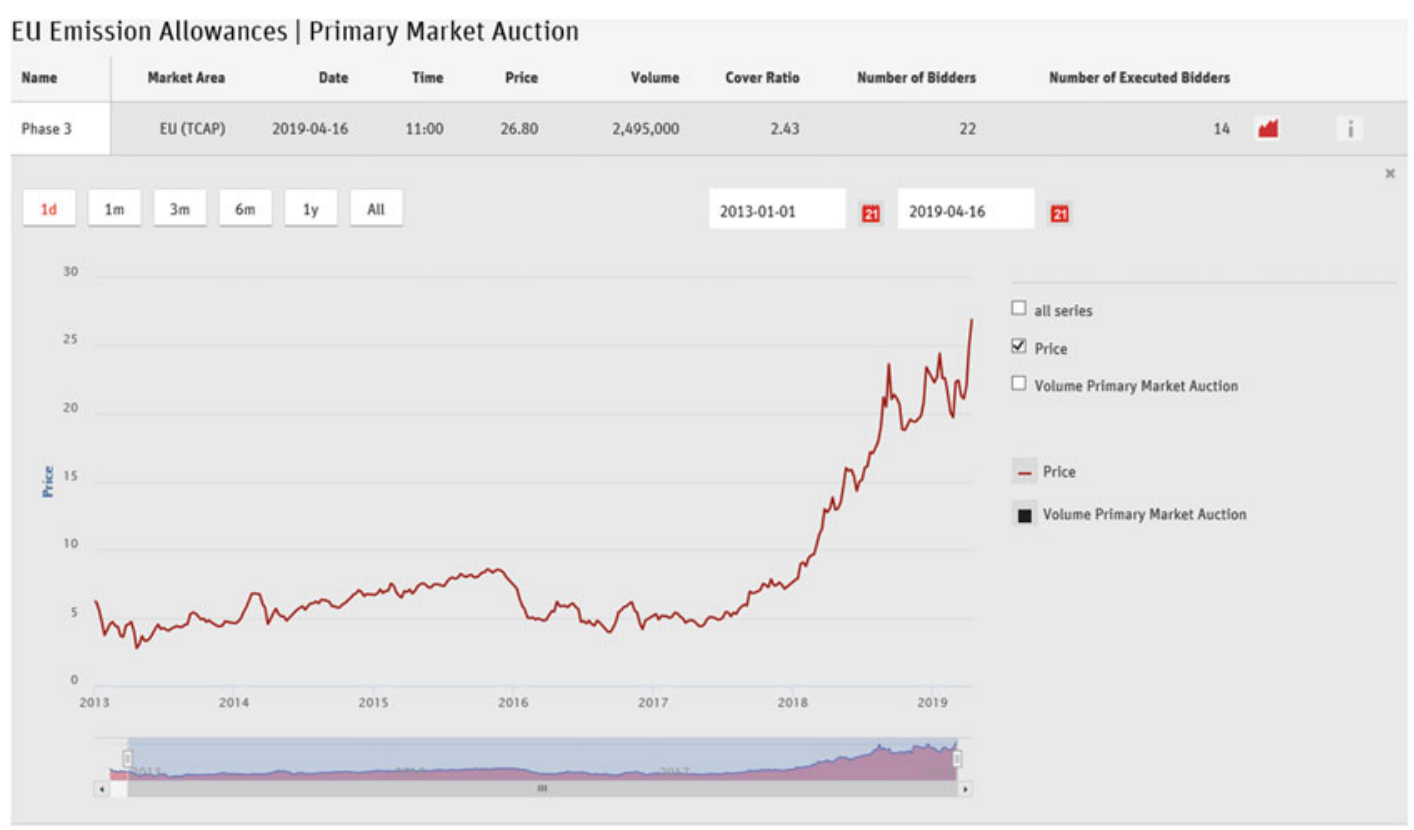

Fig. 15.2 EUA price development 2013-2018 (auction). (Source: EEX 2018)

available on the country level, while some indicators were not available for all EU28+ countries (e.g. GDP for Liechtenstein).

Reference spatial data covering study area of EU28+ countries were obtained from Eurostat as well, specifically from its subordinate unit for geographical data management - GISCO (Geographic Information System of the COmmission). These data represent the last officially valid release from 2014.

The absolute data (instead of relative) were used for the analysis because the initial emission target (the emission cup) was set as \% decrease of the total amount of the greenhouse gas emissions. Emission target was set for the EU as a whole the EU ETS follows a "cap-and-trade" approach: the EU sets a cap on how much greenhouse gas pollution can be emitted each year, and companies need to hold European Emission Allowance (EUA) for every ton of $\mathrm{CO}_{2}$ they emit within one calendar year.

Geovisual analytics was used to evaluate the development of greenhouse gas emissions and complementary macroeconomic indicators spatially. For this purpose, data from 2005 (EU ETS system came into a force) and 2015 were visualised. Geovisual analytics is described as the science of analytical reasoning and decision-making with geographic information, facilitated by interactive visual interfaces, computational methods, and knowledge construction, representation and management strategies (Andrienko et al. 2007). Geovisual analytics was performed with the use of two cartographical approaches - (1) categories (colours assigned to each qualitative information, or group of information sharing common attribute), and (2) proportional symbol technique (symbol size varies according to the attribute-quantitative measure).

For the first case (categories), Figs. 15.3, 15.4, 15.5 and 15.6, colours were complemented with the number expressing a percentage difference between 2005 and 2015, i.e. yellow colour stands for a decrease, and violet colour stands for the increase. Colours are chosen to stimulate reading the map by highlighting the countries values. As for the proportional symbol technique, for figures in Appendix, intervals were set with the use of Jenks method (natural breaks), which maximise differences between intervals, and at the same time minimise differences inside intervals (Jenks, 1967). Target five intervals were adjusted 


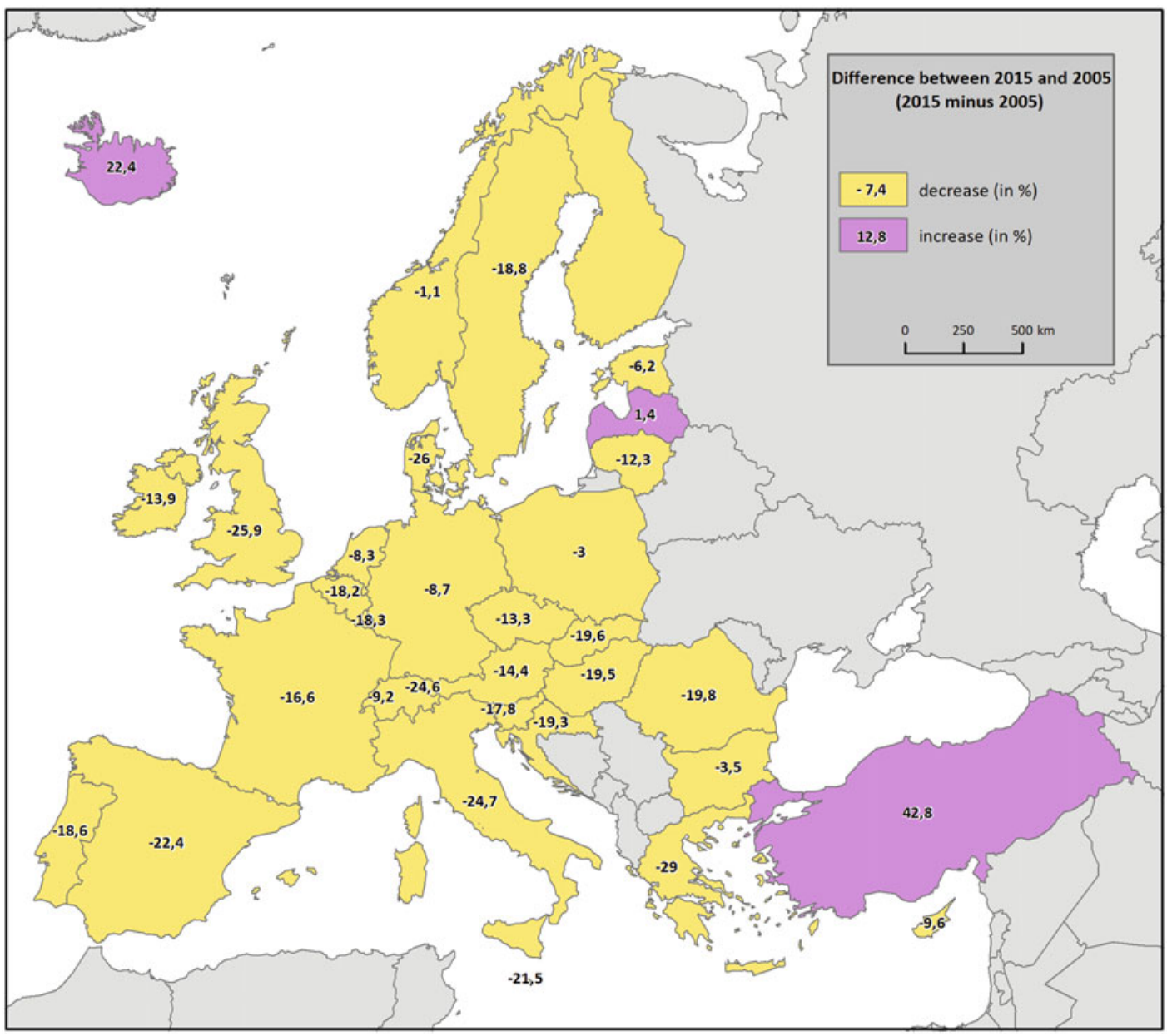

Fig. 15.3 Total $\mathrm{CO}_{2}$ emissions (difference 2005, 2015). (Source: Eurostat 2018; Authors)

according to cartographical rules for interval border-values (Voženílek et al. 2011). Abovementioned basic methods of thematic cartography allow to display, analyse, and understand source data more efficiently due to the geographical context inherent in data.

\subsection{Results}

Geovisualisation of greenhouse gases emissions in two reference years - the year 2005 (EU ETS introduction) and year 2015 (after 10 years of EU ETS) is presented in the Appendix, specifically in Figs. 15.7a, 15.7b, 15.8a and 15.8b. These maps show the total amount of $\mathrm{CO}_{2}$ emissions and the number of emissions in the energy sector. As a relative increase and decrease in the values of monitored indicators is the main subject to evaluation, and do not refer about total sums (values), it is appropriate to take into account also absolute values. This applies mainly in the case of small countries (geographically or economically). Therefore, the Appendix contains maps with the absolute values of the monitored indicators using a mentioned proportional symbols method. It is interesting to confront the (geo)visual analysis presented in the next paragraph with the corresponding maps in Appendix.

Figures 15.3 and 15.4 show the differences in the amount of greenhouse gas emissions in the individual countries involved in the EU ETS 


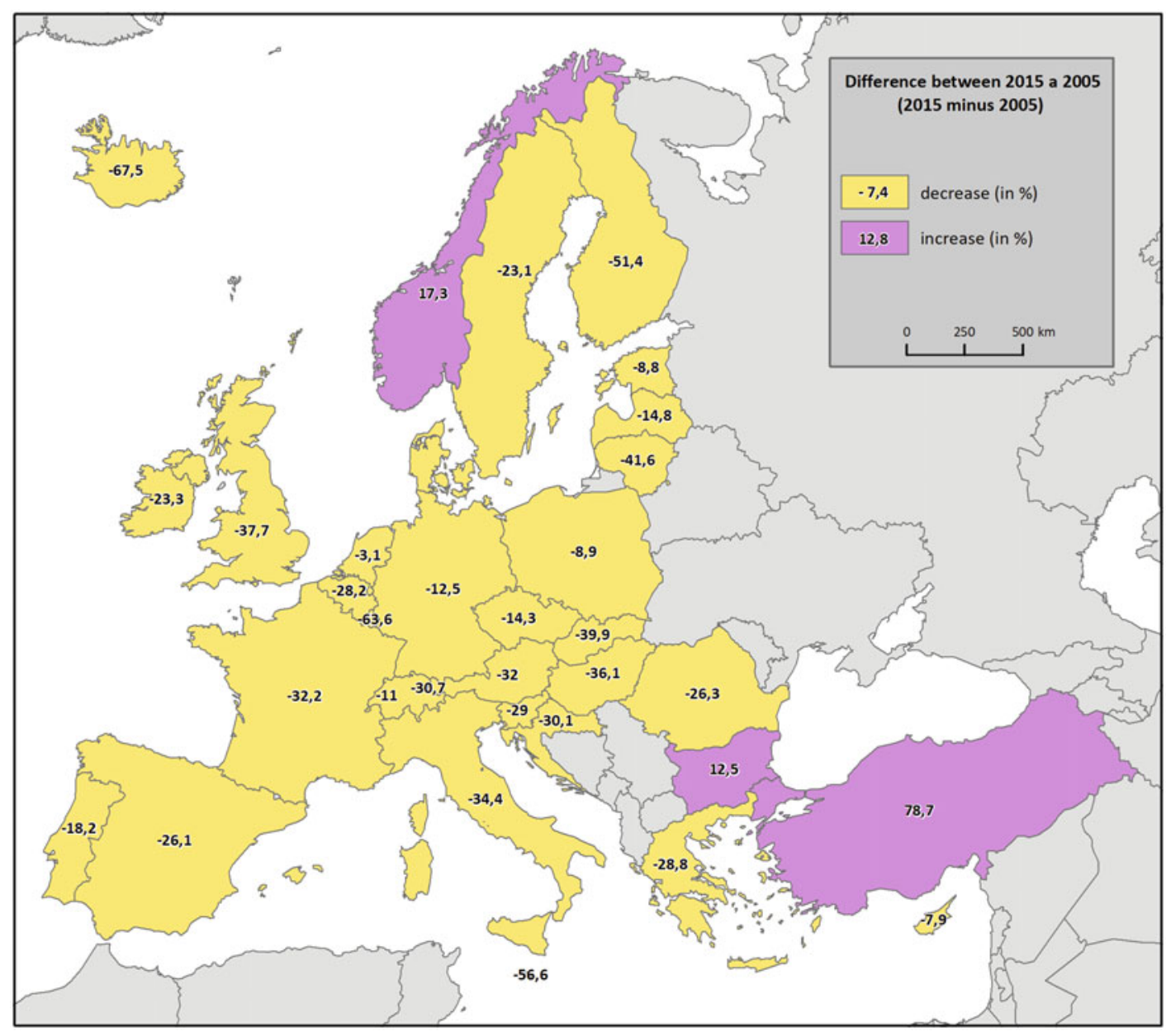

Fig. 15.4 $\mathrm{CO}_{2}$ emissions in the energy sector (difference 2005, 2015). (Source: Eurostat 2018; Authors)

between 2005 (the year of the EU ETS introduction) and 2015. Firstly (Fig. 15.3) total $\mathrm{CO}_{2}$ emissions are displayed and in Fig. 15.4, the difference in the amount of greenhouse gas emissions in the energy sector only is depicted. Regarding the development of $\mathrm{CO}_{2}$ emissions in the analysed period, it is clear that the amount of greenhouse gas emissions were reduced in all countries except Turkey, Iceland and Latvia. Overall, the decrease ranges from 29 (Greece) to $1.1 \%$ (Norway). The Czech Republic with a total $\mathrm{CO}_{2}$ emissions reduction of $13.3 \%$ belongs to the group of countries with a smaller decrease. However, neighbouring Poland and Germany showed even lower cuts (3.0, and 8.7 respectively).
On the other hand, Turkey significantly (by $42.8 \%$ ) increased overall $\mathrm{CO}_{2}$ production over the 10 years. Interestingly, Iceland, which is characterised by environmental friendliness, showed a $22.4 \%$ increase in total $\mathrm{CO}_{2}$ emissions over the period under review. What's more surprising is that in the production of $\mathrm{CO}_{2}$ in the energy sector, Iceland is the first in terms of its reduction - a drop of $67.5 \%$. It must be noted that in the case of Iceland, the absolute emission values are low (compared to other countries). That is why it is important also to confront these findings with the absolute numbers displayed in maps in Appendix. The amount of $\mathrm{CO}_{2}$ decline, as regards only the energy sector (Fig. 15.4), varied from 67.5 (Iceland) to $3.1 \%$ (the 


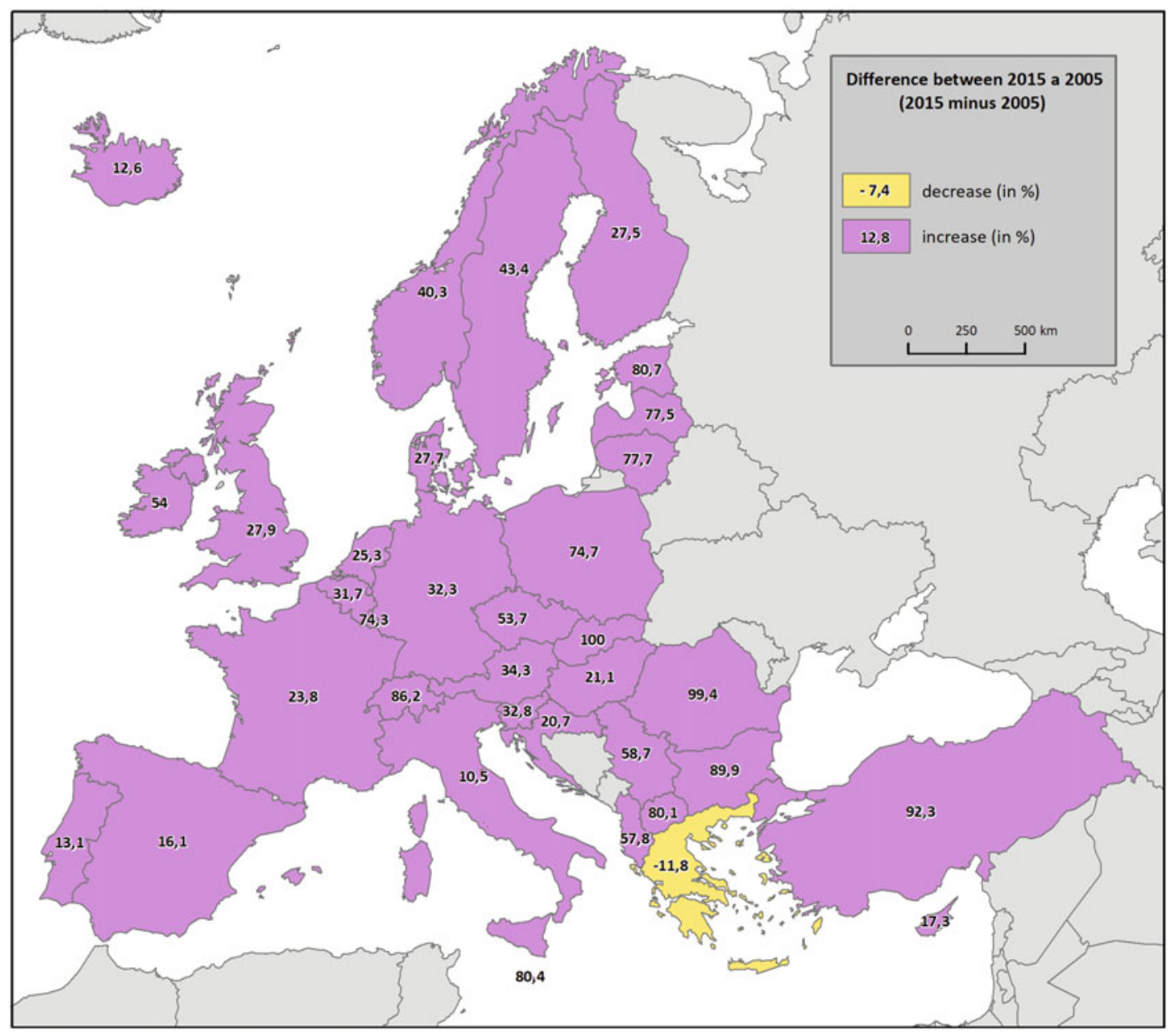

Fig. 15.5 GDP difference 2005 and 2015. (Source: Eurostat 2018; Authors)

Netherlands). The Czech Republic is part of the group of countries with a low decline. On the contrary, emissions in Turkey rose again, up $78.7 \%$, which is alarming. Increase of emissions can also be observed in Bulgaria (12.5\%) and Norway (17.3\%) but again - taking absolute values into account, it is not that dramatic.

Within the framework of the (geo)visual analysis, selected macroeconomic indicators were also examined. Figure 15.5 shows the difference in GDP as a whole and Fig. 15.6 shows the difference in investments (gross capital formation), again in the period 2005 and 2015 in the European countries (Fig. 15.9a and 15.9b, respectively Fig. $15.10 \mathrm{a}$ and $15.10 \mathrm{~b}$ in Appendix). Gross domestic product (GDP) grew in all states, except for Greece, where a decrease of $11.8 \%$ within the observed period is recorded. It should be noted, however, that the growth in the southern European countries (Portugal, Spain, Italy, Cyprus) was the lowest among all other countries (from approximately from $10 \%$ to $17 \%$ ). These low ratios are significant, especially in comparison with the younger EU member states and Turkey - all these economies increased their GDP in tens of per cent (often exceeding 50\%). Moreover, Slovakia and Bulgaria have even doubled their GDP in the monitored period. The low performance of southern European countries can be linked with the financial crisis affecting most of the "western" economies and which took place in 2008 (roughly in the middle of the observed 


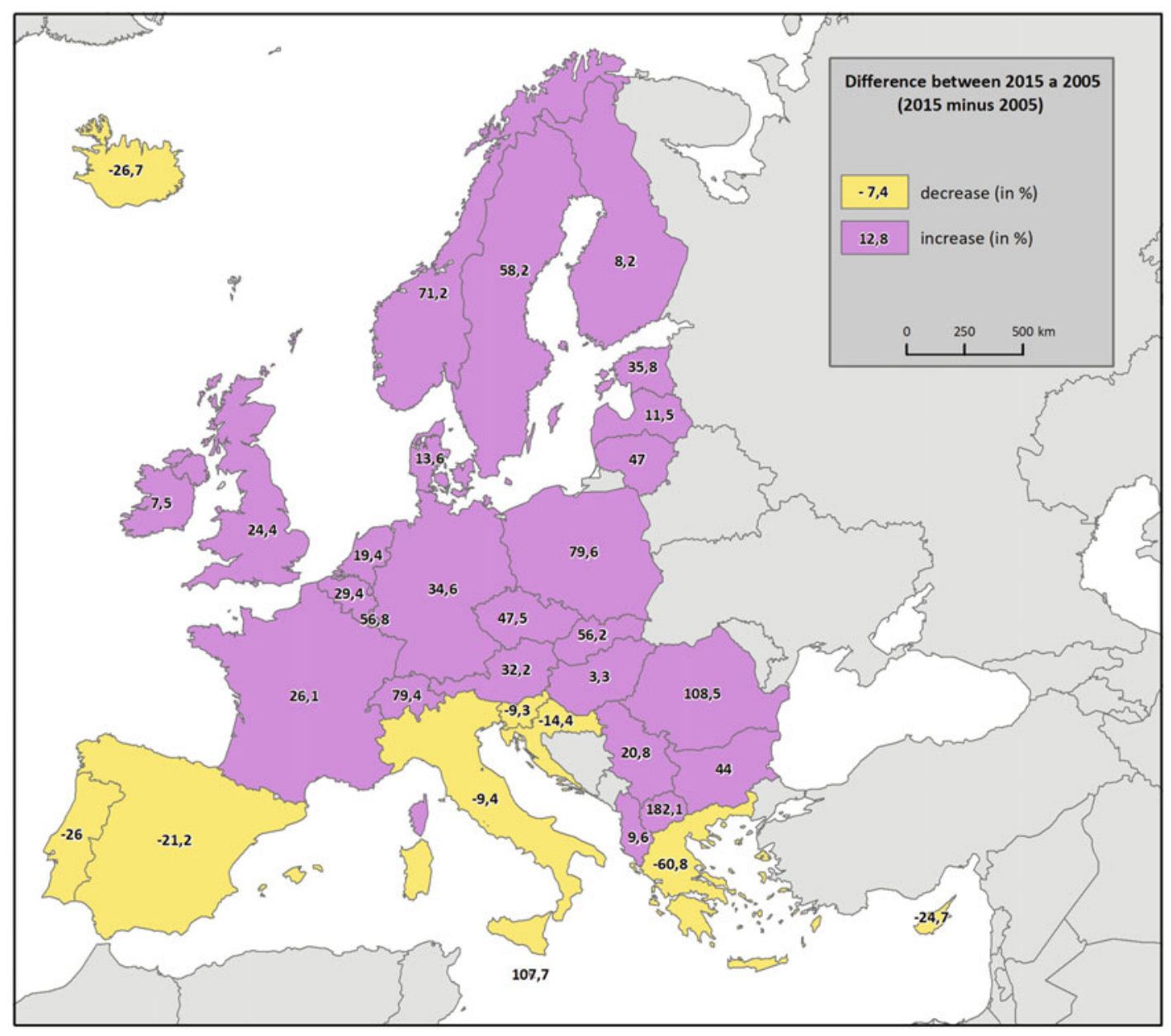

Fig. 15.6 Investments difference 2005 and 2015. (Source: Eurostat 2018; Authors)

period). In traditionally strong economies, the growth was lower (around $20 \%$ to $30 \%$ ) as those countries have a smaller potential for growth in comparison with new member states. However, economies in Switzerland, Luxembourg and Ireland showed an increase above 50 per cent.

As for the investments (Fig. 15.6), the situation is slightly different, but it follows the previous one since this indicator (investments) are connected to the GDP. In many countries, there is a decline in the number of investments, especially in southern European countries - Portugal, Spain, Italy, Greece, and Cyprus. These countries have simultaneous lowest GDP growth (or a decline in the case of Greece). Other countries with declining investments are Iceland, Slovenia and Croatia. However, the cause of the fall in investments in these countries may be different or not so closely linked to GDP growth/decline. Generally, in the traditionally strong economies (e.g. the United Kingdom, France, Germany, Austria, and Benelux countries), the increase in investments is around 19 to 35 per cent. Significant increase in investments (more than 70\%) in the 10 years can be observed in Norway, Switzerland, Poland, Romania and North Macedonia. The reasons leading to this increase differs from country to country and should be studied in more detailed together with other socio-economic data.

The key question is, whether the observed decline in $\mathrm{CO}_{2}$ emissions is related to the 
reduction of the environmental impact of the economy, due to clean technologies and energy savings introduction, or rather due to decrease in investment activities and lower production in the observed countries.

\subsection{Discussion}

The (geo)visual analysis of spatial data clearly shows the division of the monitored states into three groups - the southern states, the western and northern states (the traditional strong EU states), and the young member states (the EU member states since 2004). The most visible impact of the economic crisis in 2008 and the following years is reflected in the production of greenhouse gas emissions (both in total and in the energy sector), GDP and investment in the southern states. The group of southern states, i.e. countries from Portugal through Italy and Greece to Cyprus, can be described as representatives of economies with slow GDP growth (even a decline for Greece) and drop in investments within the observed period. The EU's younger states (those entered EU in 2004 and onwards) seem to be making the most of the benefits of EU membership, which is confirmed by both GDP and investment growth (and may be linked to the reduction of $\mathrm{CO}_{2}$ emissions through the possible promotion of eco-technologies). Traditional EU countries have not such growth potential as the younger states, but the decrease in emissions, as well as the growth of GDP and investment, is also evident in these countries. However, this trend is not as dynamic as in the group of young EU countries.

In the light of the spatial character of this economic instrument, further research on tradable emission allowances should be a more comprehensive spatial analysis focusing on the possible different effects of EU ETS in the individual Member States and a difference or similarity in the cost of avoiding pollution. Moreover, another set of indicators can be added into the analysis (e.g. sectoral employment rates, measures on the quality of life, entrepreneurial data etc.) which would require the application of some multivariate statistical methods. Especially the cluster analysis would be of perfect use since it could be applied both non-spatially and spatially. Following comparison of results might reveal some geographical dependencies among countries and shed light on the whole EU ETS system.

\subsection{Conclusions}

The chapter describes a very contemporary topic from various aspects - historical, legal, economic and also geographical. The primary methodological approach lies in the "simple" (geo)visual analysis of the indicators' representation in the form of maps. However, the "simplicity" of interpretation is based on a proper cartographic depiction of given data. If geographical displays (maps) are cartographically correct, they can transfer the information more easily, quickly, and comprehensively than presenting the data in tables.

This contribution combines purely economic data with the geographical (cartographical) methods which bring the added values in the analysis of the (spatial) pattern of environmental pollution and related economic issues. I have been clearly shown which regions of EU and associated countries are responsible for high $\mathrm{CO}_{2}$ emissions, what is their progress in this manner throughout the studied period, and how these emissions are inter-connected with the major (and basic) economic indicators. This study demonstrates benefits of the "spationomy", i.e. the fusion of GIScience (geomatics, geography, cartography and other disciplines) and economy (and its data sources), which could be very effectively employed in any research in the field of spatial exploration of economic data. 


\section{Appendix}

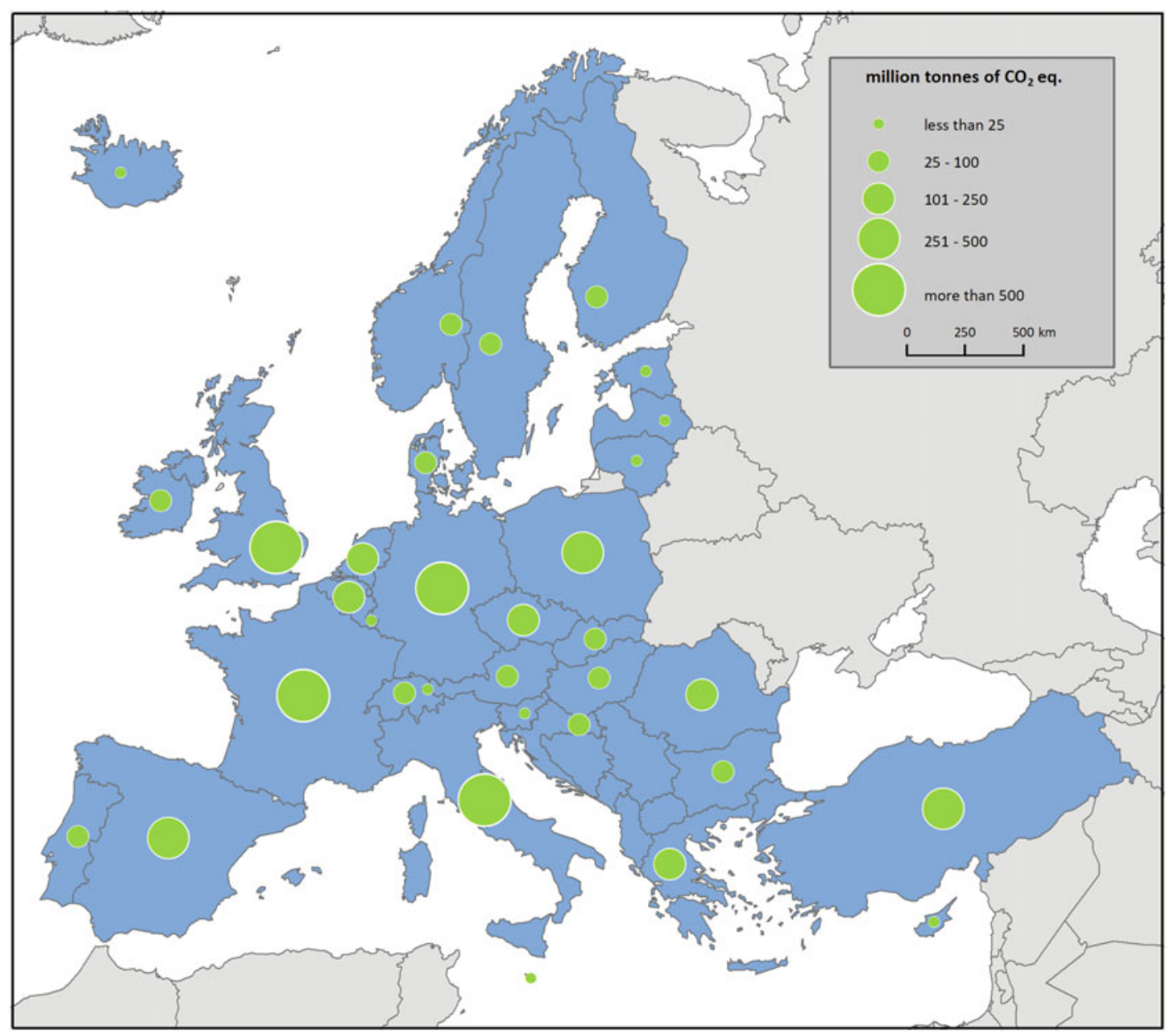

Fig. 15.7a $\mathrm{CO}_{2}$ emissions in EU countries in 2005. (Source: Eurostat 2018; Authors) 


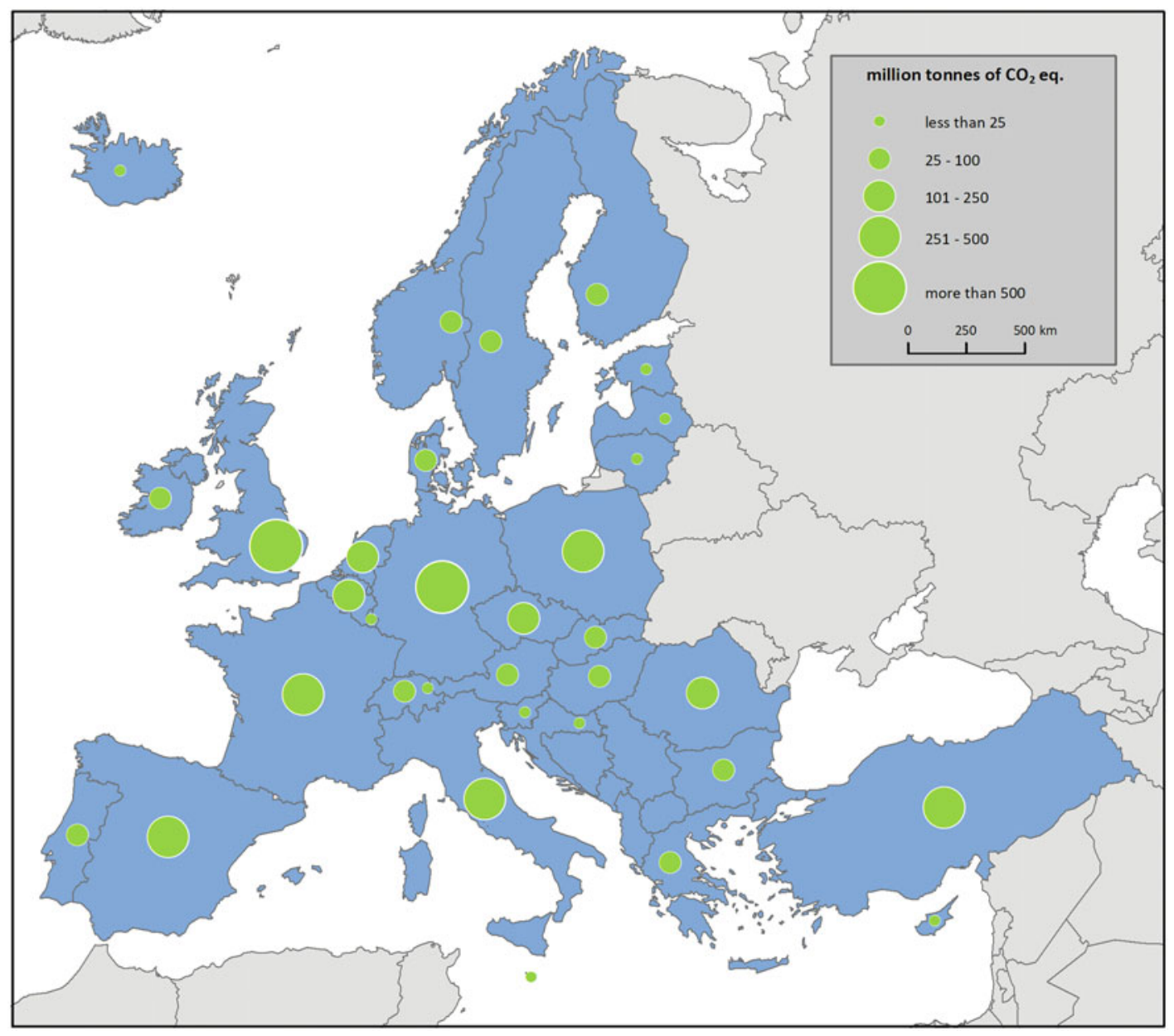

Fig. 15.7b $\mathrm{CO}_{2}$ emissions in EU countries in 2015. (Source: Eurostat 2018; Authors) 


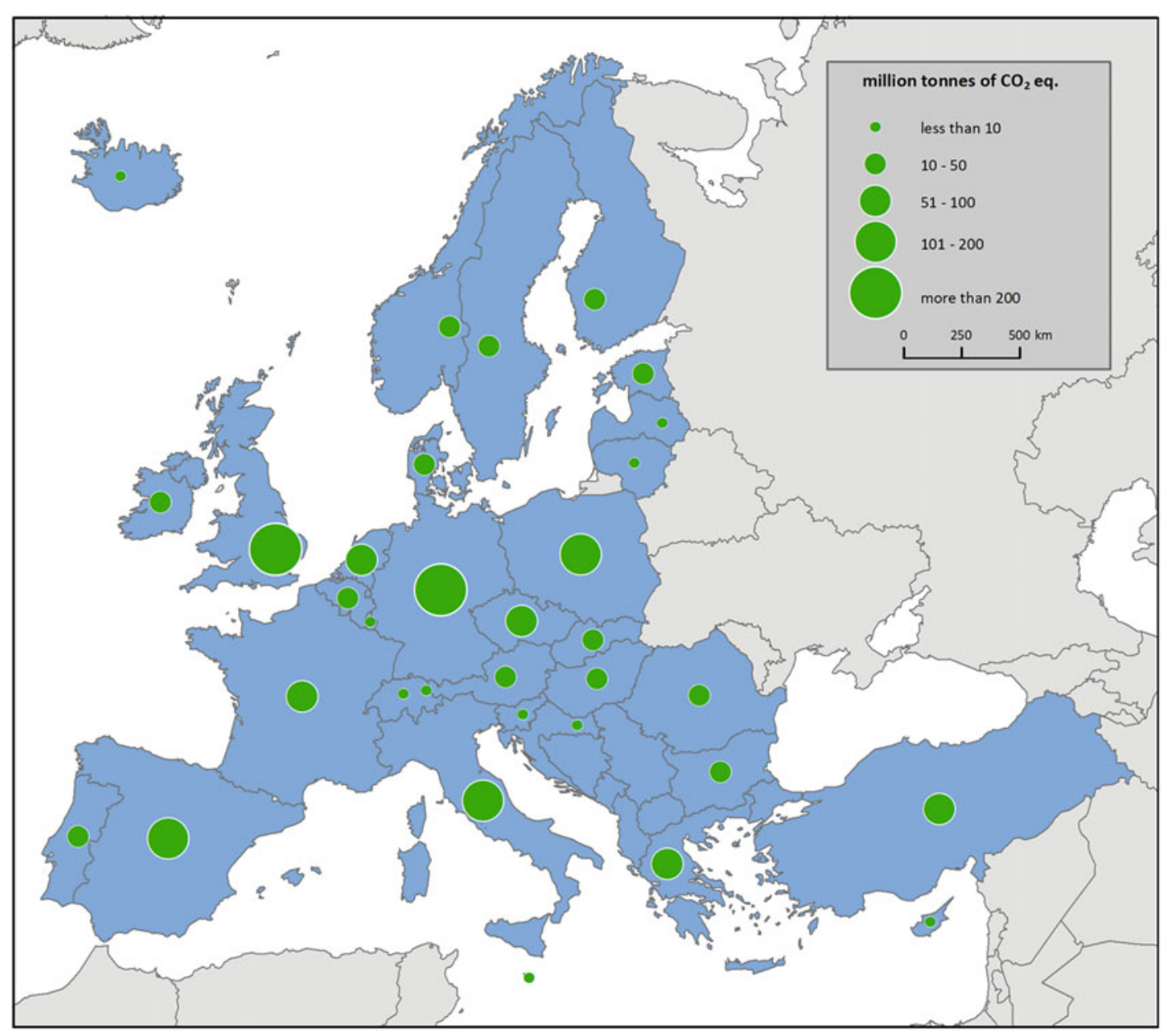

Fig. 15.8a $\mathrm{CO}_{2}$ emissions in energy sector in EU countries in 2005. (Source: Eurostat 2018; Authors) 


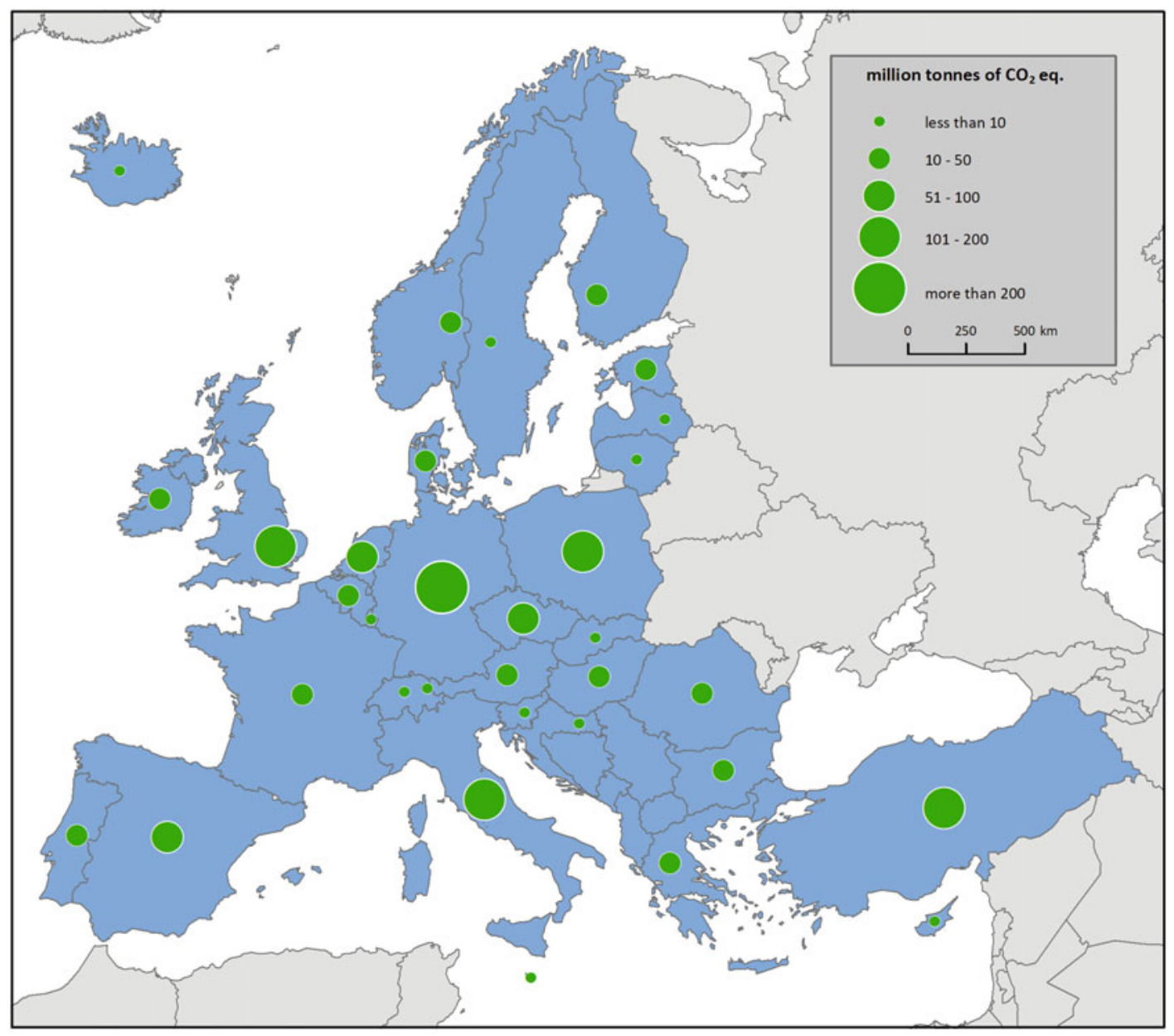

Fig. 15.8b $\mathrm{CO}_{2}$ emissions in energy sector in EU countries in 2015. (Source: Eurostat 2018; Authors) 


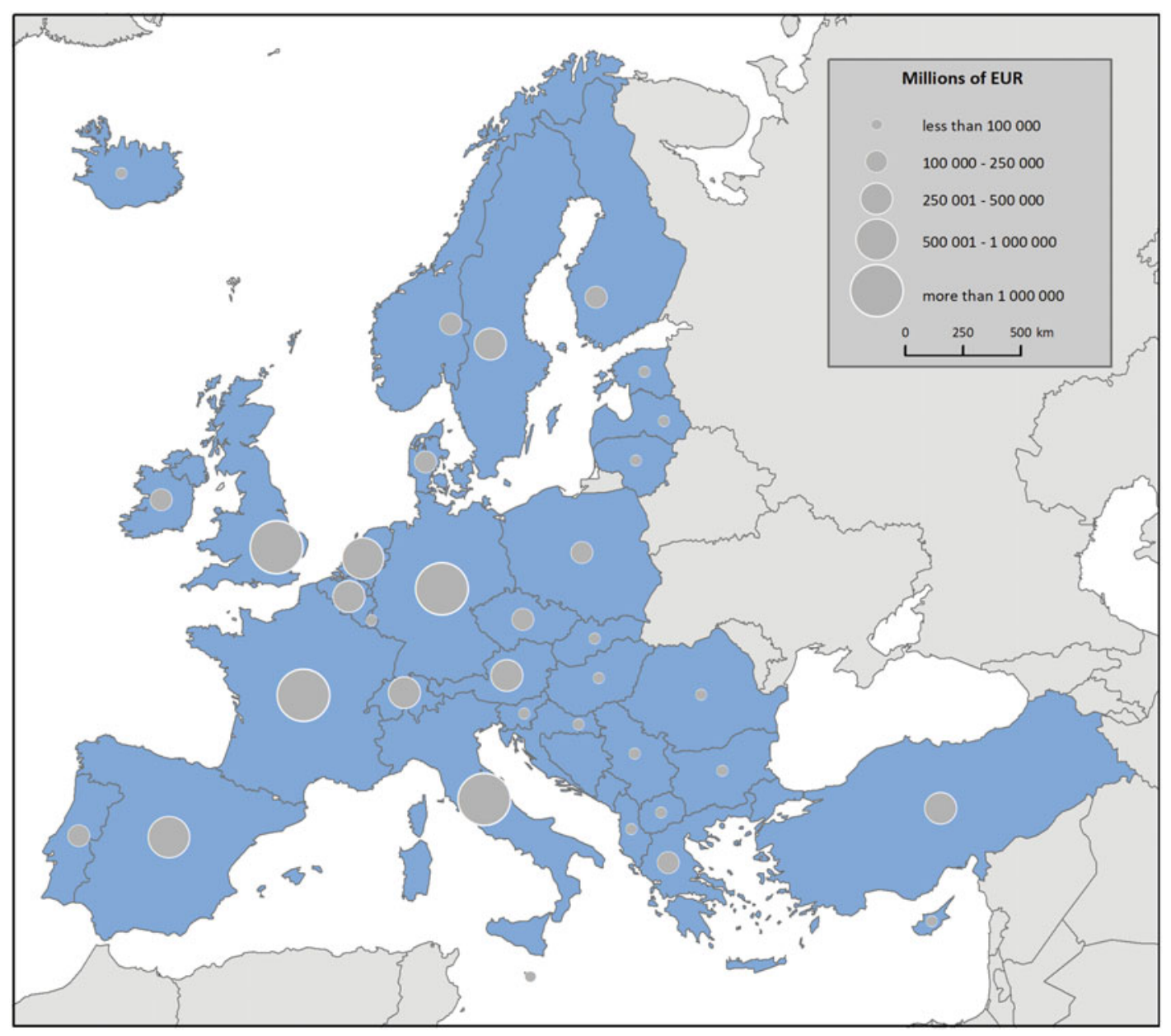

Fig. 15.9a GDP in EU countries in 2005. (Source: Eurostat 2018; Authors) 


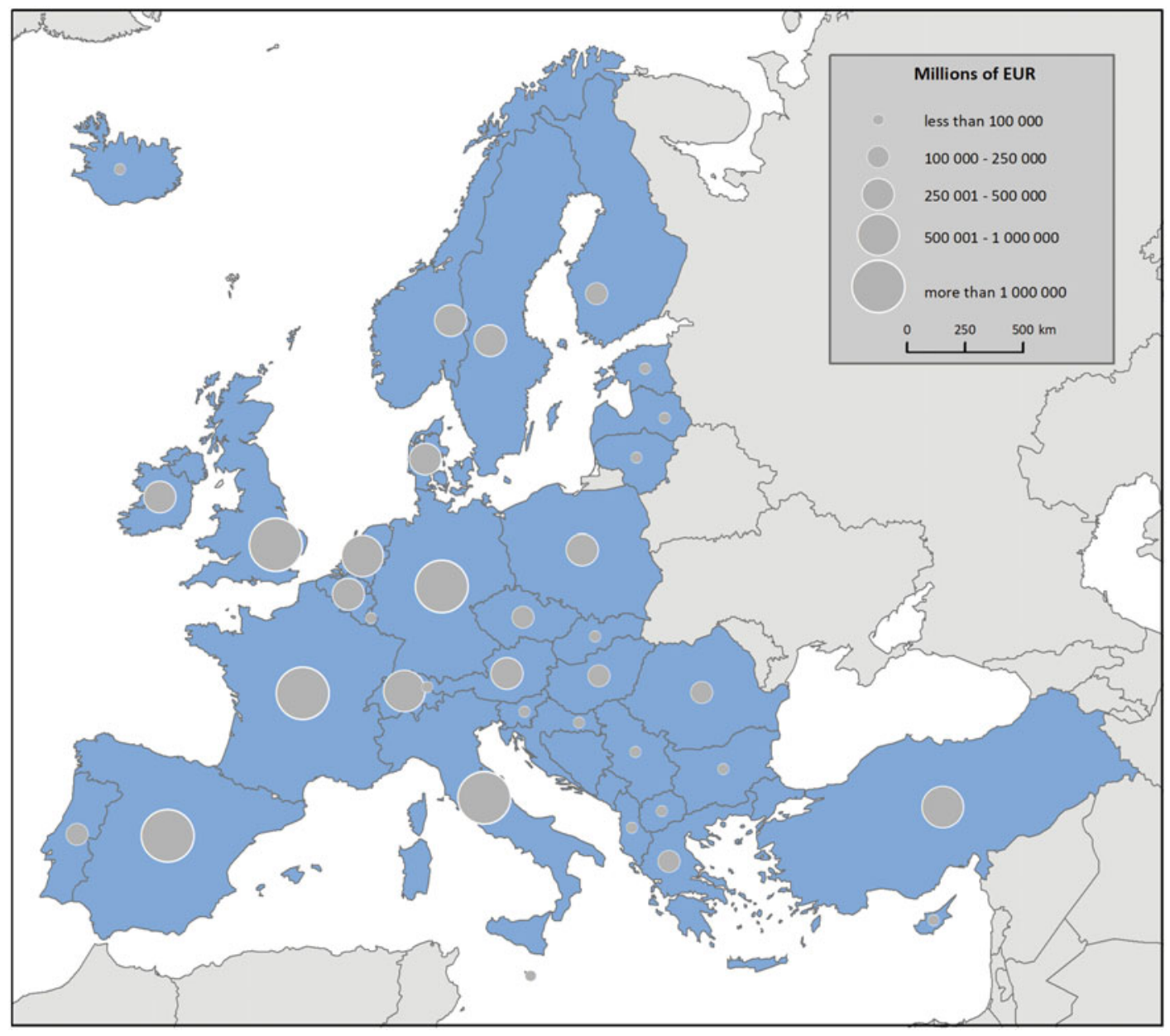

Fig. 15.9b GDP in EU countries in 2015. (Source: Eurostat 2018; Authors) 


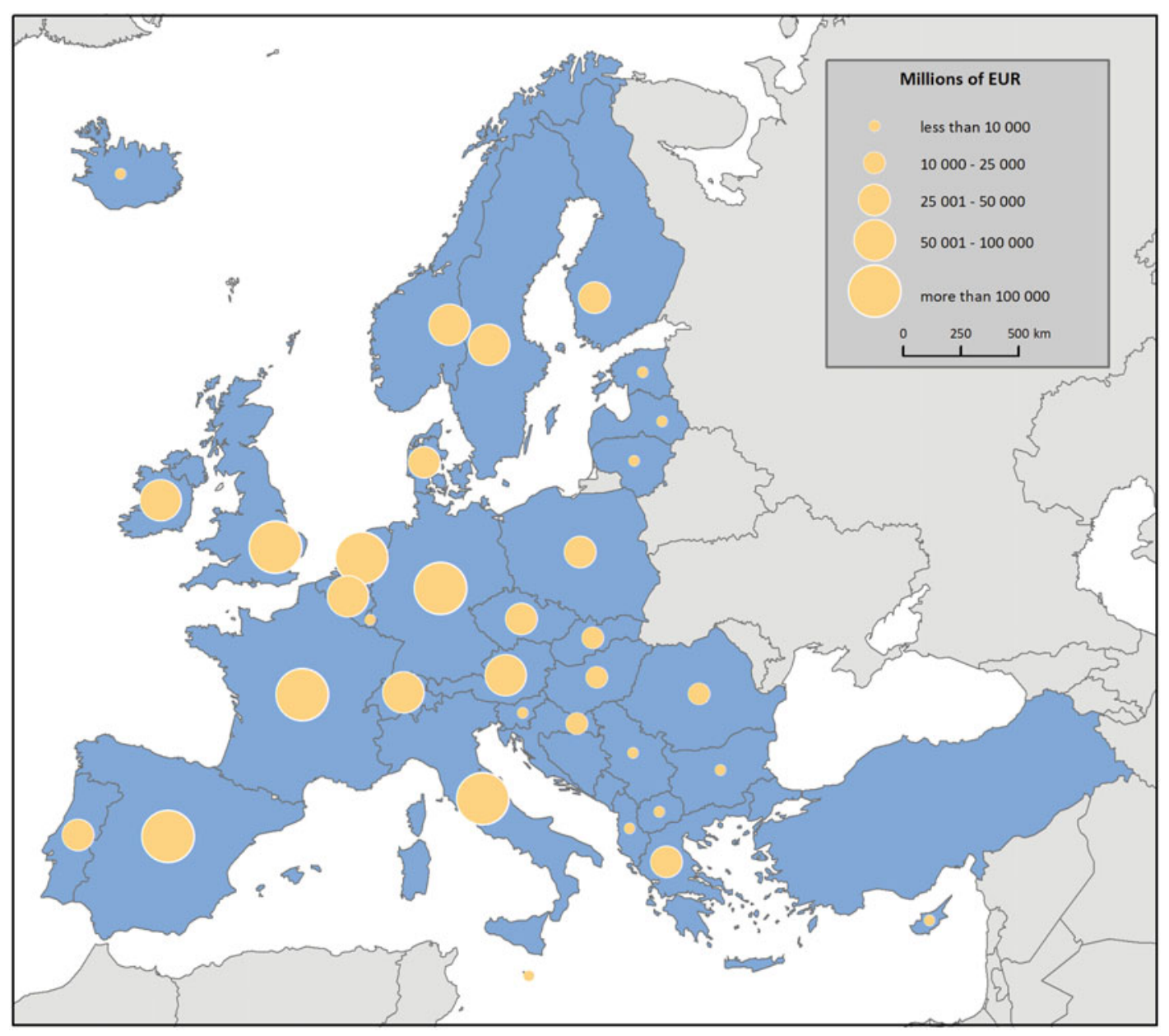

Fig. 15.10a Investments in EU countries in 2005. (Source: Eurostat 2018; Authors) 


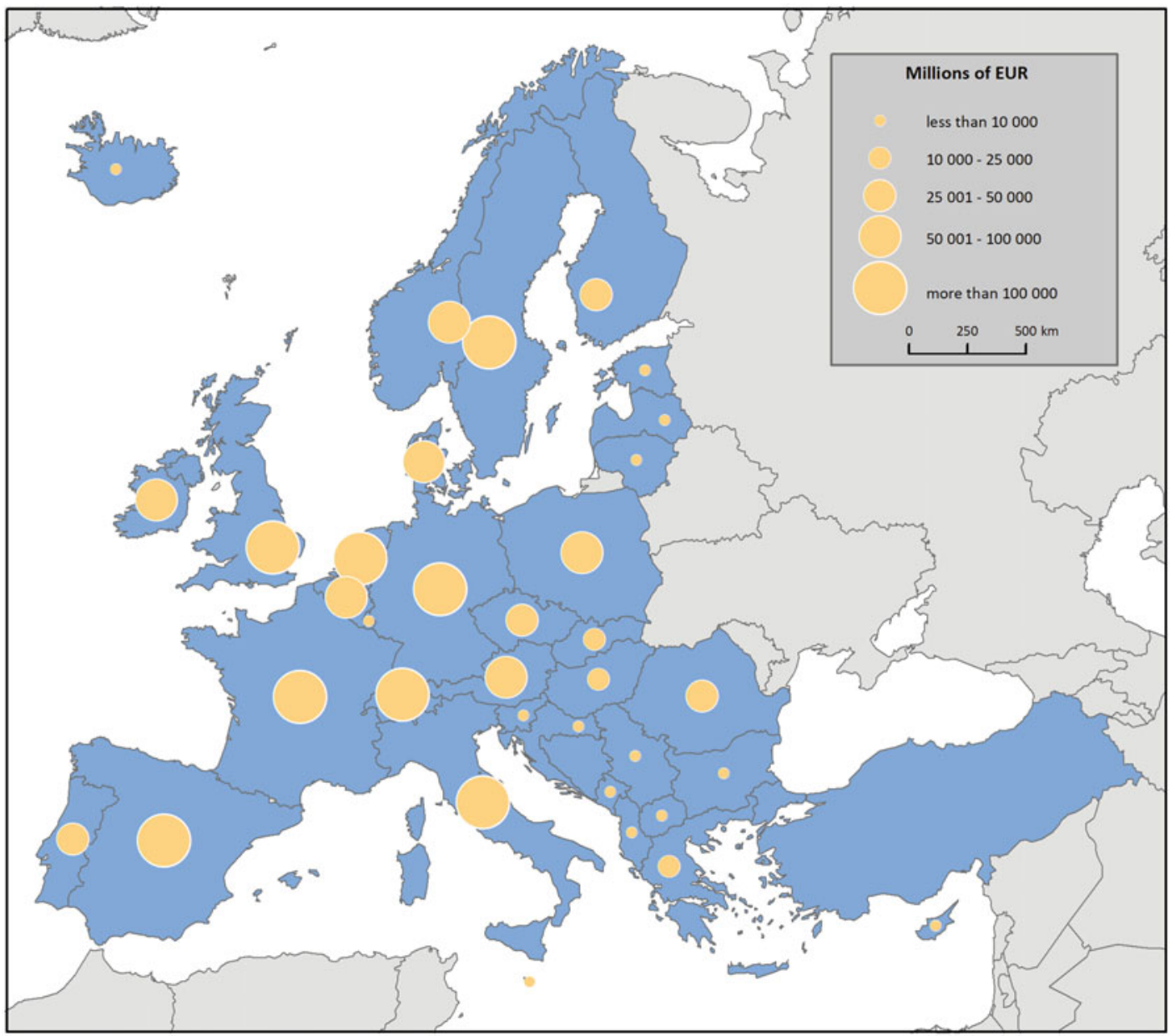

Fig. 15.10b Investments in EU countries in 2015. (Source: Eurostat 2018; Authors)

\section{References}

Aatola, P., Ollikainen, M., \& Toppinen, A. (2013). Price determination in the EU ETS market: Theory and econometric analysis with market fundamentals. Energy Economics, 36, 380-395.

Andrienko, G., Andrienko, N., Jankowski, P., Keim, D., Kraak, M. J., MacEachren, A., \& Wrobel, S. (2007). Geovisual analytics for spatial decision support: Setting the research agenda. International Journal of Geographical Information Science, 21(8), 839-857.

Benz, E., \& Trück, S. (2009). Modeling the price dynamics of $\mathrm{CO}_{2}$ emission allowances. Energy Economics, 31(1), 44-15.
BLUENEXT. (2012). EU emission allowances databases. Available at: http://www.bluenext.eu/

EEX. (2018). EU emission allowances - Prices and trading volumes. Available at: https://www.eex.com.

European Commission. (2013). The EU emissions trading system (EU ETS). European Union. October, 2013. Available at: http://ec.europa.eu/clima/publications/ docs/factsheet_ets_en.pdf.

Eurostat. (2018). Greenhouse gas emissions. GDP and its components. Available at: http://ec.europa.eu/eurostat/

Falbo, P., Felletti, D., \& Stefani, S. (2013). Free EUAs and fuel switching. Energy Economics, 2013(35), 14-21.

Jenks, G. F. (1967). The data model concept in statistical mapping. International Yearbook of Cartography, 7, 186-190. 
OECD. (2002). Indicators to measure decoupling of environmental pressure from economic growth (SG/SD (2002)/1/FINAL). Available at: http://www.oecd.org/ officialdocuments/publicdisplaydocumentpdf/? doclanguage $=$ en $\&$ cote $=\mathrm{sg} / \mathrm{sd}(2002) 1 /$ final
Voženílek, V., Kaňok, J., et al. (2011). Metody tematické kartografie-Vizualizace prostorových jevi̊. Univerzita Palackého v Olomouci. 216 p.

Wettestad, J., Eikeland, P. O., \& Nilsson, M. (2012). EU climate and energy policy: A hesitant supranational turn? Global Environmental Politics, 12(2), 65-84.

Open Access This chapter is licensed under the terms of the Creative Commons Attribution 4.0 International License (http://creativecommons.org/licenses/by/4.0/), which permits use, sharing, adaptation, distribution and reproduction in any medium or format, as long as you give appropriate credit to the original author(s) and the source, provide a link to the Creative Commons licence and indicate if changes were made.

The images or other third party material in this chapter are included in the chapter's Creative Commons licence, unless indicated otherwise in a credit line to the material. If material is not included in the chapter's Creative Commons licence and your intended use is not permitted by statutory regulation or exceeds the permitted use, you will need to obtain permission directly from the copyright holder. 